\title{
Photochemistry of copper(II) chlorocomplexes in acetonitrile: Trapping the ligand-to-metal charge transfer excited state relaxations pathways
}

\author{
Andrey S. Mereshchenko ${ }^{a, b}, *$, Pavel K. Olshin ${ }^{a}$, Artur M. Karimov ${ }^{a}$, Mikhail Yu. Skripkin ${ }^{a}$, \\ Kim A. Burkov ${ }^{a}$, Yury S. Tveryanovich ${ }^{a}$, Alexander N. Tarnovsky ${ }^{b, c}$ \\ a Institute of Chemistry, Saint-Petersburg State University, 198504 Saint-Petersburg, Russian Federation \\ ${ }^{\mathrm{b}}$ Center for Photochemical Sciences, Bowling Green State University, Bowling Green, $\mathrm{OH}$ 43403, USA

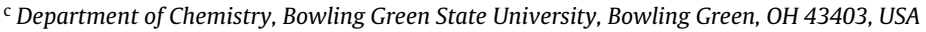

\section{A R T I C L E I N F O}

\section{Article history:}

Received 14 July 2014

In final form 7 October 2014

Available online 14 October 2014

\begin{abstract}
A B S T R A C T
Photochemistry of $\left[\mathrm{Cu}(\mathrm{MeCN})_{3} \mathrm{Cl}\right]^{+},\left[\mathrm{Cu}(\mathrm{MeCN}) \mathrm{Cl}_{3}\right]^{-}$, and $\left[\mathrm{CuCl}_{4}\right]^{2-}$ copper(II) chlorocomplexes in acetonitrile solution is studied by means of the combination of the steady-state photolysis and ultrafast transient absorption methods. The main relaxation pathways of the initially excited ligandto-metal charge transfer states are internal conversion to the ground state, ionic dissociation without (photo)reduction of copper(II), and radical dissociation with (photo)reduction of copper(II). The copper(II)-to-copper(I) photoreduction quantum yields obtained from steady-state photolysis correlate with ultrafast spectroscopy data. The presence of oxygen does not affect the photoreduction quantum yields, which do not exceed $7 \%$ for the complexes studied and decrease in the series: $\left[\mathrm{Cu}(\mathrm{MeCN})_{3} \mathrm{Cl}\right]^{+}>\left[\mathrm{Cu}(\mathrm{MeCN}) \mathrm{Cl}_{3}\right]^{-}>\left[\mathrm{CuCl}_{4}\right]^{2-}$.
\end{abstract}

(c) 2014 Elsevier B.V. All rights reserved.

\section{Introduction}

Metals play essential role in metabolism of living organisms, including humans [1-7]. In photobiology, copper-based proteins are responsible for electron transfer in photosynthesis processes [8-10], and their photoexcitation into ligand-to-metal charge transfer (LMCT) excited states is regarded as an 'analog of the actual biological electron transfer' [11]. Ultrafast photochemistry of copper complexes in a sub-picosecond time domain is best studied for blue copper proteins [11-18]. It was demonstrated that upon LMCT excitation, these systems relax non-radiatively predominantly back to the electronic ground state, either directly $[12,13,16-18]$ or cascading through the manifold of lower-lying ligand field (LF) excited states $[11,14,15]$ in less than 1 ps. Much less is known regarding photochemical reactions of these complexes on much longer time scales. On the other side, for a great number of simple copper complexes, steady-state photochemical studies were performed

\footnotetext{
* Corresponding author at: Department of Chemistry, Saint-Petersburg State University, 26 Universitetsky pr., Petrodvorets, 198504 Saint-Petersburg, Russian Federation.

E-mail address: andreym@chem.spbu.ru (A.S. Mereshchenko).
}

revealing quite interesting photochemistry [19-26], but almost no ultrafast data have been reported to date.

The LMCT excited states arise as a result promotion of an electron from ligand-localized fully occupied orbitals to a singlyoccupied d-orbital of a copper ion. The LMCT excited states of copper(II) complexes have been thoroughly reviewed in the literature [27] and demonstrated to be repulsive along a copper-ligand chemical bond $[28,29]$. Therefore, $\mathrm{Cl} \rightarrow \mathrm{Cu}(\mathrm{II})$ LMCT excitation is expected to result in redox $\mathrm{Cu}-\mathrm{Cl}$ bond breaking with the formation of copper(I) complex and chlorine atom fragments, i.e., the copper(II)to-copper(I) photoreduction and ligand oxidation [19-26]. In the most steady-state photolysis studies [21-26], copper(II) halide complexes, $\left[\mathrm{CuX}_{n}\right]^{2-n}$ upon LMCT excitation are thought to be dissociative, forming a copper(I) halide $\left[\mathrm{CuX}_{n-1}\right]^{2-n}$ complex and a halogen atom $\mathrm{X}^{\bullet}$, which subsequently undergo oxidation or halogenation reactions. However, copper(II)-to-copper(I) quantum yields are small, especially for copper(II) chloride complexes, where it do not exceed $13 \%$ for acetonitrile and methanol solutions $[21,25]$.

Whereas the photochemistry of copper(II) complexes upon LMCT excitation has been widely studied, revealing the copper(II)to-copper(I) photoreduction as a primary photochemical reaction, the explanation of small photoreaction quantum yields as well as effects of solvents and ligand on the photoreduction quantum yield has not been offered. In the present work, we used the combination 
of steady-state laser photolysis and femtosecond transient absorption spectroscopy methods with different excitation wavelengths to reveal main relaxation pathways of different LMCT excited states.

\section{Experimental}

Copper(II) perchlorate hexahydrate (98\%), tetraethylammonium perchlorate (>98\%), tetraethylammonium chloride (>98\%), copper powder (>99\%), murexide, ethylenediaminetetraacetic acid disodium salt aqueous solutions $(0.1 \mathrm{M})$, ammonium chloride ( $\geq 99.5 \%$ ), ammonium hydroxide aqueous solutions (28.0-30.0\%), and acetonitrile (>99.5\%) were purchased from Sigma-Aldrich. Tetraethylammonium chloride, tetraethylammonium perchlorate, and lithium chloride were dried in vacuum oven at $110^{\circ} \mathrm{C}$ for $10 \mathrm{~h}$. Chloroacetone (95\%) was purchased from Alfa Aesar and used without additional purification. Tetrakis (acetonitrile) copper(I) perchlorate was prepared as described previously [30,31]. To prepare copper(II)-containing solutions, first, a stock solution of copper(II) perchlorate, $\mathrm{C}\left(\mathrm{Cu}^{2+}\right)=0.2 \mathrm{M}$, was prepared by dissolving copper(II) perchlorate hexahydrate into acetonitrile followed by complexometric titration using an ethylenediaminetetraacetic acid disodium salt solution $(0.1 \mathrm{M})$ and murexide as titrant and indicator, respectively, in an ammonium chloride ( $0.1 \mathrm{M})$-ammonium hydroxide $(0.1 \mathrm{M})$ buffer solution.

For the global fitting of titration UV-vis absorbance measurements to a specific chemical reaction mechanism, which allows the determination of equilibrium constants of the involved species, ReactLab EQUILIBRIA software was used [32]. 'Medusa' software [33] was used to calculate the fraction distribution of the complexes presented in the solution based on the input values of stability constants and the initial concentrations of the components (in the case under consideration, $\mathrm{Cu}\left(\mathrm{ClO}_{4}\right)_{2}$ as a source of copper(II) ions, and $\mathrm{NEt}_{4} \mathrm{Cl}$ as a source of chloride ions).

For steady-state photolysis of copper(II) acetonitrile solutions, continuous laser irradiation at 266,308, 325, 405, and $489 \mathrm{~nm}$ wavelengths was used. About $3 \mathrm{ml}$ of the copper(II) solutions in a $1 \mathrm{~cm} \times 1 \mathrm{~cm} \times 4 \mathrm{~cm}$ quartz cuvette with the absorbance greater than 2 at the irradiation wavelength were photolyzed for 10-120 min. To remove dissolved atmospheric oxygen, the solutions were purged with argon for $1 \mathrm{~h}$. The photoreduction quantum yields were determined by measuring the copper(II) concentration before $\left(C_{0}\right)$ and after $(C(t))$ exposure to the laser light using the procedure in which $1 \mathrm{ml}$ of the $200 \mathrm{mM} \mathrm{NEt}_{4} \mathrm{Cl}$ solution was added to $0.1 \mathrm{ml}$ of the analyzed solution to convert all copper(II) into $\mathrm{CuCl}_{4}{ }^{2-}$, which absorption spectrum in was measured a $1 \mathrm{~cm}$ cell. The concentration change plotted versus the irradiation time was fitted by a linear function to determine the rate of the copper(II) concentration decrease, $\Delta C,\left(C(t)=C_{0}-\Delta C t\right)$. Copper(II) perchlorate $(0.1-10 \mathrm{mM})$ solutions in acetonitrile were used for calibration procedure (Fig. $6 \mathrm{~S}$, Supplementary materials). The 408-nm absorbance depended linearly on the copper(II) concentration and was not affected by the addition of copper(I) (up to $10 \mathrm{mM}$ ). Photon flux $F$ (in mol s${ }^{-1}$ units) at the irradiation wavelength $\lambda$ was determined from the laser power $P$ (measured using an UNO laser power meter, STANDA) according to the equation:

$F=\frac{P \lambda}{h c N_{A}}$,

where $h$ is the Planck constant, $c$ is the speed of light in vacuum, $N_{A}$ is the Avogadro number. The copper(II)-to-copper(I) photoreduction quantum yield was calculated as $\Phi_{\mathrm{cu}(\mathrm{II}) \rightarrow \mathrm{Cu}(\mathrm{I})}=\Delta C V / F$, where

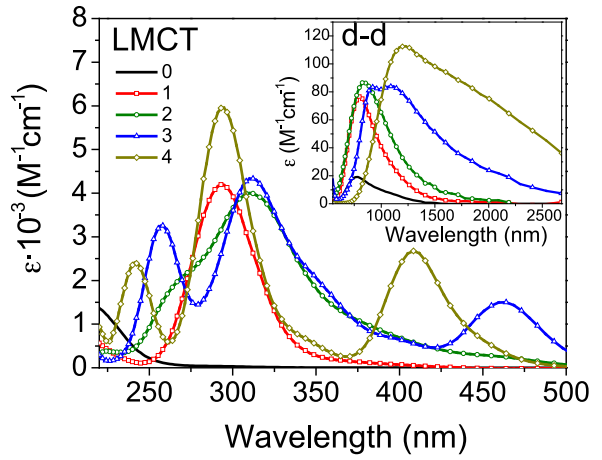

Figure 1. Steady-state absorption spectra of the individual copper(II) chlorocomplexes, $\mathrm{CuCl}_{n}^{2-n}$, where $n=0-4$, in acetonitrile.

$V$ is the sample volume $\left(3 \times 10^{-3} \mathrm{~L}\right), \Delta$ is the rate of the copper(II) concentration decrease, and $\mathrm{F}$ is the photon flux.

The transient absorption spectra were measured using the experimental set-up based on regeneratively amplified Ti: sapphire laser system (800 nm, $1 \mathrm{kHz}$ ) described previously [30,34]. An optical parametric amplifier (OPA) was used to generate $266,310,420$, 490-nm excitation ('pump') pulses with energies of 7, 7, 9, and $5.4 \mu \mathrm{Jpulse}^{-1}$, respectively. Optical pulses from by another OPA or white-light continuum were used for probing in the $210-384 \mathrm{~nm}$ and 340-760 spectral range, respectively. The probe light was focused onto the sample to a $160-\mu$ m diameter spot and overlapped at an angle of $6^{\circ}$ with the pump light focused to a $460-\mu \mathrm{m}$ diameter spot. The polarization of the pump and probe light was set at the magic angle $\left(54.7^{\circ}\right)$ with respect to each other. The solutions were circulated through a $0.2-\mathrm{mm}$ Spectrosil UV quartz flow cell. The UV-vis-NIR-IR absorption spectra were measured using a Varian Cary 50 UV-vis, a Perkin Elmer Lambda 750 UV-vis-NIR, and a Perkin Elmer Lambda 1050 spectrophotometer. All experiments were performed at $21^{\circ} \mathrm{C}$.

\section{Results and discussion}

In the present work, we selectively photolysed three charged copper(II) chlorocomplexes: $\left[\mathrm{Cu}(\mathrm{MeCN})_{3} \mathrm{Cl}\right]^{+},\left[\mathrm{Cu}(\mathrm{MeCN}) \mathrm{Cl}_{3}\right]^{-}$, and $\left[\mathrm{CuCl}_{4}\right]^{2-}$. It is well known that in acetonitrile, copper(II) ions form a $\left[\mathrm{Cu}^{\mathrm{II}}(\mathrm{MeCN})_{4}\right]^{2+}$ solvatocomplex [35,36]. Upon addition of chloride ions, the formation of $\left[\mathrm{Cu}^{\mathrm{II}}(\mathrm{MeCN})_{4-n} \mathrm{Cl}_{n}\right]^{2-n}(n=1-4)$ chlorocomplexes takes place, according to Scheme 1.

Thereafter, solvent molecules will be omitted for clarity. Copper(II) chlorocomplexes with different number of chloride ligands have different UV-vis absorption spectra [37]. We measured the absorption spectra from 220 to $2680 \mathrm{~nm}$ of a set of 15 solutions containing $10 \mathrm{mM} \mathrm{Cu}\left(\mathrm{ClO}_{4}\right)_{2}-200 \mathrm{mM}\left(\mathrm{NEt}_{4} \mathrm{Cl}, \mathrm{NEt}_{4} \mathrm{ClO}_{4}\right)$, where the concentration of $\mathrm{NEt}_{4} \mathrm{Cl}$, the source of chloride ions, was varied from 0 to $200 \mathrm{mM}$ (Fig. 1S, Supplementary materials), to obtain the absorption spectra of the individual chlorocomplexes in a wide spectral range and clarify the overall stability constants derived by Ishiguro and co-workers [37] using a much narrower range of wavelengths. Having performed the analysis of the measured spectra using ReactLab EQUILIBRIA software [32], the absorption spectra of the individual chlorocomplexes (Figure 1) and the overall stability constants in acetonitrile $\left(\beta_{1}=3.4 \times 10^{8}\right.$, $\beta_{2}=4.3 \times 10^{15}, \beta_{3}=2.8 \times 10^{22}$, and $\beta_{4}=5.1 \times 10^{25}$ ) were determined, close to values obtained by Ishiguro and co-workers

$$
\left[\mathrm{Cu}^{\mathrm{II}}(\mathrm{MeCN})_{4}\right]^{2+}+\mathrm{nCl}^{-} \leftrightarrow\left[\mathrm{Cu}^{\mathrm{II}}(\mathrm{MeCN})_{4-\mathrm{n}} \mathrm{Cl}_{\mathrm{n}}\right]^{2-\mathrm{n}}+\mathrm{nMeCN}(\mathrm{n}=1-4)
$$


Table 1

Copper(II)-to-copper(I) photoreduction quantum yields for different copper(II) chlorocomplexes in acetonitrile.

\begin{tabular}{|c|c|c|c|c|}
\hline Excited complex & Solution composition & $\begin{array}{l}\text { Excitation wavelength } \\
(\mathrm{nm})\end{array}$ & $\begin{array}{l}\text { Quantum yield aerobic } \\
(\%)\end{array}$ & $\begin{array}{l}\text { Quantum yield anaerobic } \\
(\%)\end{array}$ \\
\hline $\mathrm{CuCl}^{+}$ & 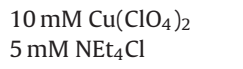 & $\begin{array}{l}266 \\
308\end{array}$ & $\begin{array}{l}4.5 \pm 0.7 \\
5.2 \pm 0.7\end{array}$ & $\begin{array}{l}4.5 \pm 0.7 \\
6.2 \pm 0.7\end{array}$ \\
\hline $\mathrm{CuCl}_{3}^{-}$ & 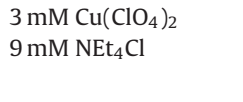 & $\begin{array}{l}266 \\
325 \\
489\end{array}$ & $\begin{array}{l}1.4 \pm 0.4 \\
1.3 \pm 0.4 \\
1.3 \pm 0.4\end{array}$ & $\begin{array}{l}1.0 \pm 0.4 \\
1.3 \pm 0.4 \\
1.7 \pm 0.4\end{array}$ \\
\hline $\mathrm{CuCl}_{4}{ }^{2-}$ & $\begin{array}{l}1 \mathrm{mM} \mathrm{Cu}\left(\mathrm{ClO}_{4}\right)_{2} \\
200 \mathrm{mM} \mathrm{NEt}_{4} \mathrm{Cl}\end{array}$ & $\begin{array}{l}308 \\
405\end{array}$ & $\begin{array}{l}0 \\
0\end{array}$ & $\begin{array}{l}0 \\
0\end{array}$ \\
\hline
\end{tabular}

$\left(\beta_{1}=5.7 \times 10^{9}, \beta_{2}=2.3 \times 10^{17}, \beta_{3}=3.1 \times 10^{22}\right.$, and $\left.\beta_{4}=2.8 \times 10^{25}\right)$ [37].

The equilibrium concentrations of the copper(II) chlorocomplexes are generally determined by the initial concentrations of copper(II) and chloride ions (Scheme 1). Optimal initial concentrations of copper(II) perchlorate and tetraethylammonium chloride needed for the predominant preparation of $\mathrm{CuCl}^{+}, \mathrm{CuCl}_{3}{ }^{-}$, or $\mathrm{CuCl}_{4}{ }^{2-}$, and the relative concentration of the specific individual chlorocomplex in acetonitrile were estimated using the 'Medusa' software [33]. In three solutions selected: $10 \mathrm{mM} \mathrm{Cu}\left(\mathrm{ClO}_{4}\right)_{2}-5 \mathrm{mM}$ $\mathrm{NEt}_{4} \mathrm{Cl}, 3 \mathrm{mM} \mathrm{Cu}\left(\mathrm{ClO}_{4}\right)_{2}-9 \mathrm{mM} \mathrm{NEt} 4 \mathrm{Cl}_{4}$, and $1 \mathrm{mM} \mathrm{Cu}\left(\mathrm{ClO}_{4}\right)_{2}-$ $200 \mathrm{mM} \mathrm{NEt}{ }_{4} \mathrm{Cl}, \mathrm{CuCl}^{+}, \mathrm{CuCl}_{3}{ }^{-}$, and $\mathrm{CuCl}_{4}{ }^{2-}$ were the dominating complexes, which were then excited at 266 and $308 \mathrm{~nm}, 266$, 325 , and $489 \mathrm{~nm}$, and 308 and $405 \mathrm{~nm}$, respectively. $\mathrm{CuCl}_{2}$ was not studied as it was not possible to make a solution with $\mathrm{CuCl}_{2}$ as the dominating form (Fig. 2S). The aforementioned solutions were photolyzed in the presence (aerobic conditions) and the absence (anaerobic conditions) of dissolved atmospheric oxygen for the determination of the photoreduction quantum yield. The change of copper(II) concentration as a result of the irradiation, calibration concentration measurements are shown in Figs. 3S-6S and the obtained quantum yields are summarized in Table 1 .

For all complexes studied, the copper(II) photoreduction quantum yields do not depend either on the wavelength or the presence of oxygen. Our results are thus in disagreement with those of Cervone et al., who found the quantum yields to be significantly affected by the presence of oxygen [25]. A possible reason of this disagreement is the method of the copper(II) concentration quantitative analysis in the abovementioned work [25]: 'The amount of photoreaction was determined by the change in optical density of the peak of the lowest energy intense band, which is located very close to $460 \mathrm{~nm}$ for any $[\mathrm{Cu}(\mathrm{II})] /\left[\mathrm{Cl}^{-}\right]$ratio.' In fact (Figure 1 and Ref. [37]), the spectral shape strongly depends on the concentrations of the copper(II) and chloride ions, and some complexes, e.g. $\mathrm{CuCl}^{+}$and $\mathrm{CuCl}_{4}{ }^{2-}$ have no absorption at $460 \mathrm{~nm}$. Moreover, the authors did not demonstrate the correlation between the copper(II) concentration and the absorbance at $460 \mathrm{~nm}$. The lack of the dependence of the copper(II) photoreduction quantum yield on the irradiating wavelength may be evidence for fast internal conversion in the nascent LMCT state, which leads to a population of the lowest energy LMCT state followed by dissociation of the complex to form a copper(I) complex and a chlorine atom. The copper(II) photoreduction quantum yield is measured to be about 5 and $1.5 \%$ for $\mathrm{CuCl}^{+}$and $\mathrm{CuCl}_{3}{ }^{-}$complexes, respectively, whereas $\mathrm{CuCl}_{4}{ }^{2-}$ is found to be photostable. To gain further understanding of the of the copper(II) photoreaction, we performed femtosecond time-resolved transient absorption experiments to observe initial steps of this reaction (Figure 2 ).

In transient absorption $(\Delta A)$ experiments, the solution compositions and excitation wavelengths used was kept similar to those in the photoreduction quantum yield measurements, Fig. 10S. The $\Delta A$ spectra measured at $500 \mathrm{fs}$ and $1 \mathrm{~ns}$ after excitation of the $\mathrm{CuCl}^{+}, \mathrm{CuCl}_{3}{ }^{-}$, and $\mathrm{CuCl}_{4}{ }^{2-}$ complexes into their LMCT states are shown in Figures 3-6. The full set of the $\Delta A$ spectra are given in Fig. 7S-9S. The $\Delta A$ spectrum interpretation is hindered by the fact that the absorption spectra of possible photoproducts, a copper(I), $\left[\mathrm{Cu}^{\mathrm{I}}(\mathrm{MeCN})_{4}\right]^{+}$solvatocomplex (thereafter, abbreviated as $\mathrm{Cu}^{+}$) and a $\mathrm{Cl}^{\bullet} \mathrm{CH}_{3} \mathrm{CN}$ charge-transfer complex (CTC, free chlorine atoms absorb $<190 \mathrm{~nm}$ ) are not known. The absorption spectrum of the $\mathrm{Cu}^{+}$species (a very intense band peaking at $209 \mathrm{~nm}$ with $\varepsilon=19800 \mathrm{M}^{-1} \mathrm{~cm}^{-1}$ and a shoulder at) $230 \mathrm{~nm}$ ) was determined from UV-vis absorption measurements of tetrakis(acetonitrile)copper(I) perchlorate $(3 \mathrm{mM})$ dissolved in deoxygenated acetonitrile. To determine the absorption spectrum of the $\mathrm{Cl}{ }^{\bullet} \mathrm{CH}_{3} \mathrm{CN}$ CTC species, we measured the $\Delta A$ spectrum $500 \mathrm{ps}$ after 266-nm photolysis of acetonitrile solutions of chloroacetone, a precursor for photochemically produced chlorine atoms, which is the approach we used previously for CT between chlorine atoms and methanol [30]. The broad $320-370 \mathrm{~nm} \Delta A$ band is similarly assigned to the absorption of the $\mathrm{MeCN}{ }^{\bullet} \mathrm{Cl}$ CTC species (we assumed that the extinction coefficient at the absorption maximum is $4000 \mathrm{M}^{-1} \mathrm{~cm}^{-1}$, that is of the same amplitude reported for $\mathrm{Cl}^{\bullet} \mathrm{H}_{2} \mathrm{O}$ [38] and $\mathrm{Cl} \bullet \mathrm{MeOH}$ [30] CT complexes, Fig. 11S).

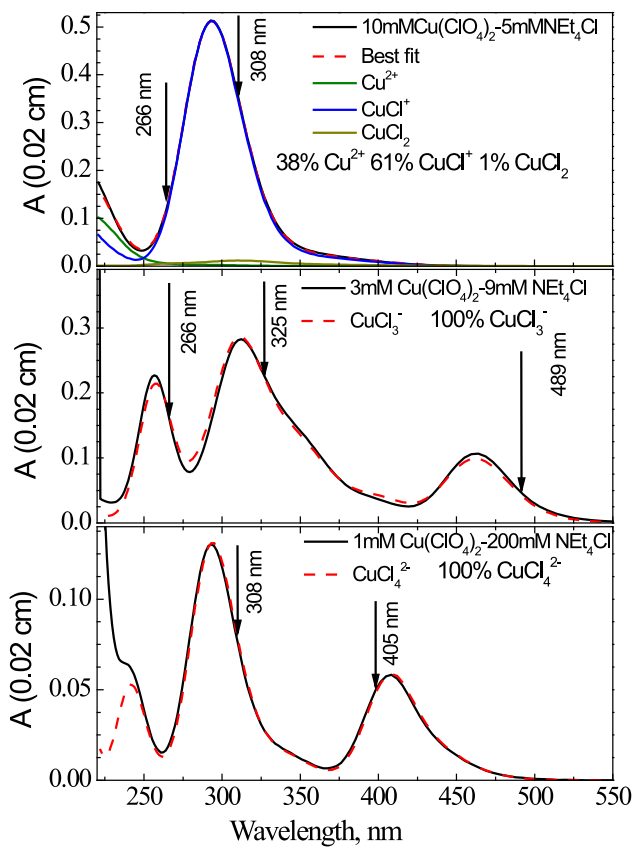

Figure 2. Top-to-bottom: absorption spectra (solid black lines) of three solutions with different proportions of $\mathrm{Cu}\left(\mathrm{ClO}_{4}\right)_{2}$ and $\mathrm{Net}_{4} \mathrm{Cl}$ used for the photoreduction quantum yield measurements. The dashed lines show the best fits of these spectra to a sum of the absorbances of the chlorocomplexes, which individual contributions are shown by solid colored lines. The legend display the fractional concentration distributions of the individual copper(II) chlorocomplexes. The arrows indicate the excitation wavelengths used in the experiments. 


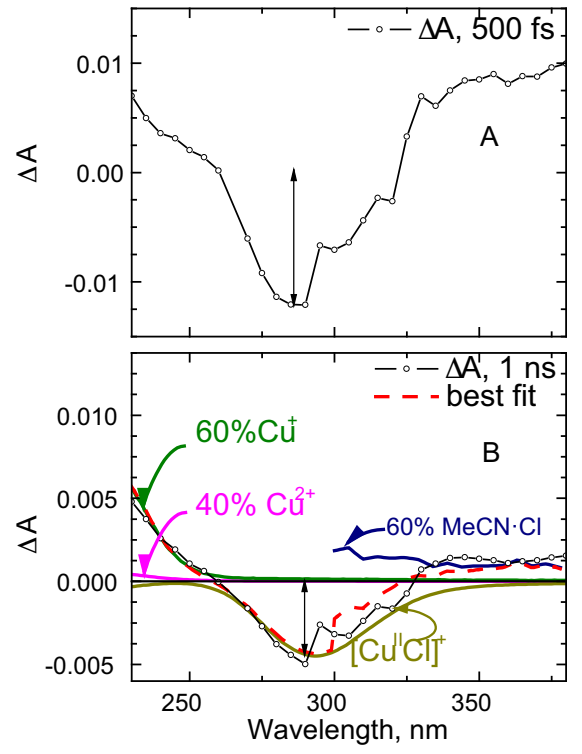

Figure 3. $500-\mathrm{fs}(\mathrm{A})$ and 1 -ns (B) transient absorption spectra of a $50 \mathrm{mM} \mathrm{Cu}\left(\mathrm{ClO}_{4}\right)_{2}$ - $25 \mathrm{mMNEt}_{4} \mathrm{Cl}$ acetonitrile solution upon $266-\mathrm{nm}$ excitation. The $\mathrm{CuCl}^{+}$complex is predominantly excited. The black arrows mark the estimated amplitudes of groundstate bleach.

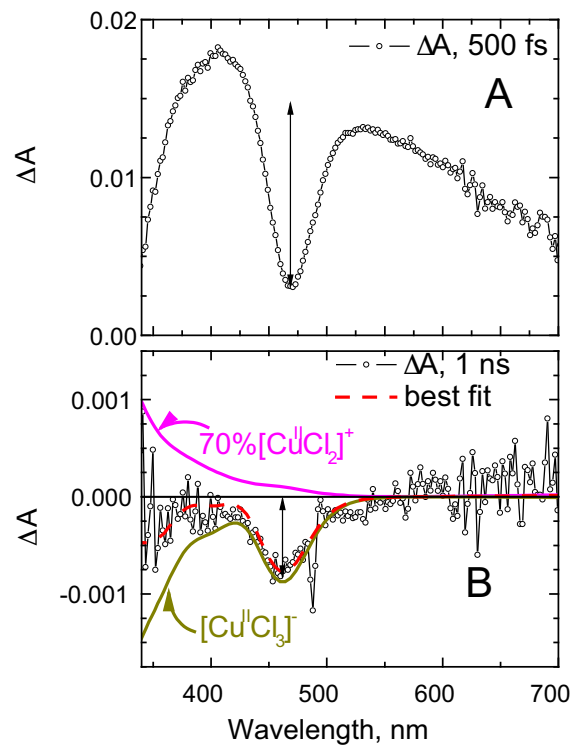

Figure 4. $500-\mathrm{fs}(\mathrm{A})$ and $1-\mathrm{ns}$ (B) transient absorption spectra of a $0.7 \mathrm{mM} \mathrm{Cu}\left(\mathrm{ClO}_{4}\right)_{2}$ - $2.1 \mathrm{mMNEt}_{4} \mathrm{Cl}$ acetonitrile solution upon 490-nm excitation. The $\mathrm{CuCl}_{3}{ }^{2-} \mathrm{com}-$ plex is predominantly excited. The black arrows mark the estimated amplitudes of ground-state bleach.

Having obtained the photoproduct absorption spectra, it is now possible to assign the $\Delta A$ spectra of $\mathrm{CuCl}^{+}, \mathrm{CuCl}_{3}{ }^{-}$, and $\mathrm{CuCl}_{4}{ }^{2-}$ in Figures 3-6. The positive 500 -fs $220-250$ and $320-400 \mathrm{~nm}$ $\triangle A$ signals upon 266-nm excitation of $\mathrm{CuCl}^{+}$can be assigned to, respectively, the absorption of the $\mathrm{Cu}(\mathrm{I})$ solvatocomplex and the superimposed absorption of the $\mathrm{Cl}{ }^{\bullet} \mathrm{MeCN}$ CT species and the $\mathrm{CuCl}^{+}$complex in the vibrationally excited ligand field (LF) excited and ground states. This assignment is made by analogy with the previously discussed photochemistry of $\mathrm{CuCl}^{+}$in methanol [30]. The negative $500-\mathrm{fs} 285-\mathrm{nm} \Delta A$ band is due to bleaching of the ground state absorption of $\mathrm{CuCl}^{+}$. The 1-ns $\Delta A$ spectrum can be satisfactorily fitted to a sum of the absorption spectra of ionic dissociation products $\left(\mathrm{Cu}^{2+}\right)$ radical dissociation products $\left(\mathrm{Cu}^{+}\right.$and $\left.\mathrm{Cl}{ }^{\bullet} \mathrm{MeCN} \mathrm{CTC}\right)$, and the parent complex $\left(\mathrm{CuCl}^{+}\right.$, the latter spectrum

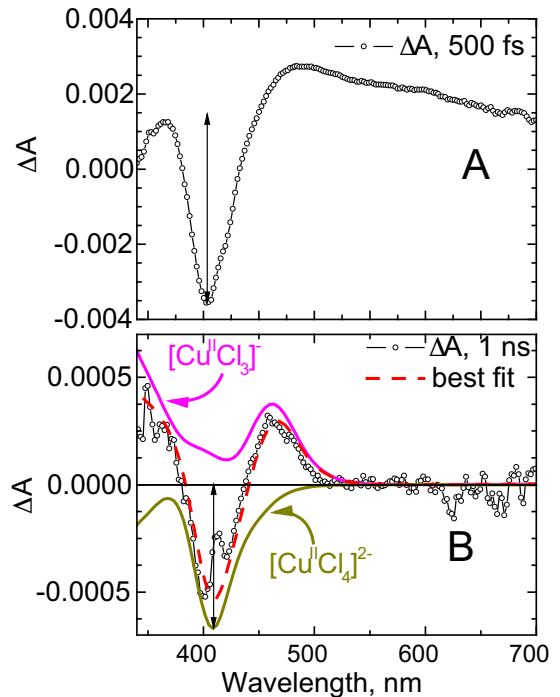

Figure 5. 500-fs (A) and 1-ns (B) transient absorption spectra of a $10 \mathrm{mM} \mathrm{Cu}\left(\mathrm{ClO}_{4}\right)_{2}$ $-200 \mathrm{mMNEt}_{4} \mathrm{Cl}$ acetonitrile solution upon 420 -nm excitation. $\mathrm{The} \mathrm{CuCl}_{4}{ }^{2-} \mathrm{complex}$ is predominantly excited. The estimated ground-state bleach amplitudes are marked by the black arrows.

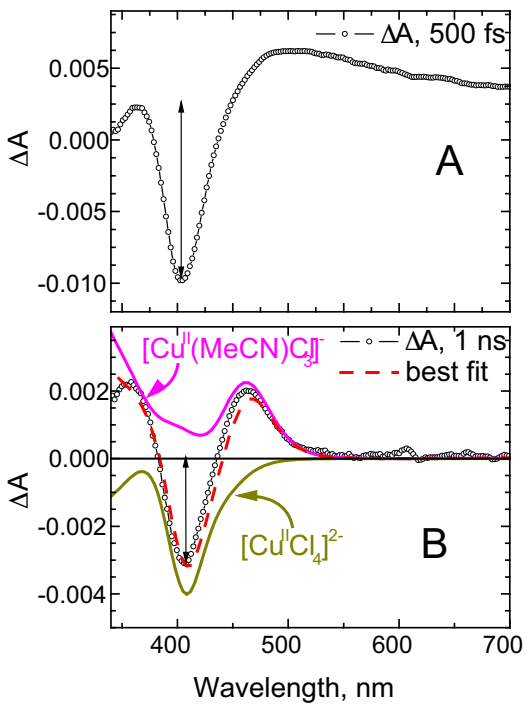

Figure 6. 500-fs (A) and 1-ns (B) transient absorption spectra of a $\left.10 \mathrm{mM} \mathrm{Cu}^{-C^{2} O_{4}}\right)_{2}$ - $200 \mathrm{mMNEt}_{4} \mathrm{Cl}$ acetonitrile solution excited at $310 \mathrm{~nm}$. The $\mathrm{CuCl}_{4}{ }^{2-}$ complex is predominantly excited. The estimated ground-state bleach amplitudes are marked by the black arrows.

contributes as ground-state bleach, and therefore, is inverted). Based on the fit, we found that at $1 \mathrm{~ns}, \mathrm{CuCl}^{+}$radical $\left(\mathrm{Cu}^{+}\right.$and $\mathrm{Cl} \cdot \mathrm{MeCN} \mathrm{CTC})$ and ionic $\left(\mathrm{Cu}^{2+}\right.$ and $\left.\mathrm{Cl}^{-}\right)$photodissociation products are formed in a ratio $3 / 2$. Comparing the negative amplitudes in the $500 \mathrm{fs}$ and $1 \mathrm{~ns} \Delta A$ spectra, one notices that the latter is about three times smaller than the former. Under the assumption that the 500-fs negative $\Delta A$ band is solely due the initial excitationinduced depopulation of the ground state of $\mathrm{CuCl}^{+}$, one can crudely estimate that of all complexes excited to the LMCT state, about $20 \%$ dissociated into $\mathrm{Cu}^{+}+\mathrm{Cl}^{\bullet}$ and $13 \%$ dissociated into $\mathrm{Cu}^{2+}+\mathrm{Cl}^{-}$at $1 \mathrm{~ns}$ after excitation, whereas the remaining $67 \%$ underwent internal conversion to the ground state.

The broad 500-fs $\Delta A$ spectrum of $\mathrm{CuCl}_{3}{ }^{-}$upon 490-nm excitation can be interpreted as the absorption of the vibrationally hot LF excited and the ground states superimposed with the ground-state bleach and the absorption of the dissociation products. The $1-n s$ 


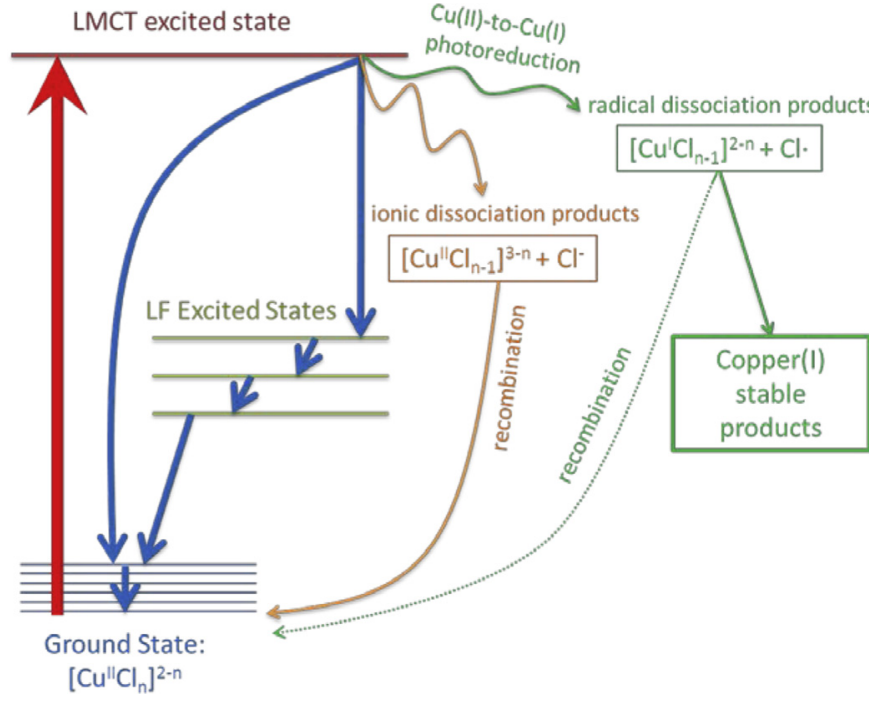

Figure 7. Relaxation paths of the LMCT-excited copper(II) chlorocomplexes.

$\triangle A$ spectrum is best fitted to a sum of the absorption of the parent $\mathrm{CuCl}_{3}{ }^{-}$complex (bleach, the negative sign) and ionic dissociation products ( $\mathrm{a} \mathrm{Cu} \mathrm{Cu}^{\mathrm{II}} \mathrm{Cl}_{2}$ complex) according to the following equation: $\Delta A_{1 \mathrm{~ns}}(\lambda)=k^{*}\left(0.7 \varepsilon_{\left[\mathrm{CuCl}_{2}\right]}(\lambda)-\varepsilon_{\left[\mathrm{CuCl}_{3}\right]^{-}}(\lambda)\right)$, where $\Delta A_{1 \mathrm{~ns}}(\lambda)$ is the 1-ns $\Delta A$ spectrum, $\varepsilon_{\left[\mathrm{CuCl}_{2}\right]}(\lambda)$ is the extinction spectrum of $\mathrm{Cu}^{\mathrm{II}} \mathrm{Cl}_{2}$, $\varepsilon_{\left[\mathrm{CuCl}_{3}\right]^{-}}(\lambda)$ is the extinction spectrum of $\mathrm{CuCl}_{3}{ }^{-}$, and $k$ is the scaling factor. Other possible photoproducts, such as $\mathrm{Cl}^{\bullet} \mathrm{MeCN} C \mathrm{CT}$ and $\mathrm{Cu}^{\mathrm{I}} \mathrm{Cl}_{2}{ }^{-}$complexes, absorb in the UV region outside the studied spectral range. The best fit demonstrates that $70 \%$ of the dissociation outcomes result in the ionic products $\left(\mathrm{Cu}^{\mathrm{II}} \mathrm{Cl}_{2}+\mathrm{Cl}^{-}\right)$. The radical dissociation products $\left(\mathrm{Cu}^{\mathrm{I}} \mathrm{Cl}_{2}{ }^{-}+\mathrm{Cl}^{\bullet}\right)$ are probably responsible for the remaining $30 \%$. Taking into account the relative amplitude of ground state bleach at $500 \mathrm{fs}$ and at $1 \mathrm{~ns}$, which is $15 / 1$, we estimated that of all $\mathrm{CuCl}_{3}{ }^{-}$excited into the LMCT state, $5 \%$ dissociated into $\mathrm{Cu}^{\mathrm{II}} \mathrm{Cl}_{2}$ and $\mathrm{Cl}^{-}$and $2 \%$ dissociated into $\mathrm{Cu}^{\mathrm{I}} \mathrm{Cl}_{2}{ }^{-}$and $\mathrm{Cl}^{\bullet}$ at $1 \mathrm{~ns}$, whereas the remaining 93\% underwent internal conversion to the ground state. As in the case of $\mathrm{CuCl}^{+}$discussed above, internal conversion in $\mathrm{CuCl}_{3}{ }^{-}$involves the relaxation to the vibrationally hot ground and LF excited states.

For $\mathrm{CuCl}_{4}{ }^{2-}$ upon 310- and 420-nm excitation, the 500-fs $\Delta A$ spectra have the same spectral shape, as well as 1-ns $\Delta A$ spectra. The 500 -fs $\Delta A$ spectra are dominated by the excitedstate absorption of vibrationally hot LF state superimposed with ground-state bleach [39]. The 1-ns $\Delta A$ spectra obey the following relationship: $\Delta A_{1 \mathrm{~ns}}(\lambda)=k^{*}\left(\varepsilon_{\left[\mathrm{CuCl}_{3}\right]^{-}}(\lambda)-\varepsilon_{\left[\mathrm{CuCl}_{4}\right]^{2-}}(\lambda)\right)$, where $k$ is the scaling factor, $\varepsilon_{[\mathrm{CuCl} 3]}-$ is the extinction spectrum of $\mathrm{CuCl}_{3}{ }^{-}$, and $\varepsilon_{\left[\mathrm{CuCl}_{4}\right]^{2-}}(\lambda)$ is the extinction spectrum the parent $\mathrm{CuCl}_{4}{ }^{2-} \mathrm{com}-$ plex, which implies that $\mathrm{CuCl}_{4}{ }^{2-}$ has only one dissociation channel and that leads to the formation of the $\mathrm{Cu}^{\mathrm{II}} \mathrm{Cl}_{3}{ }^{-}$and $\mathrm{Cl}^{-}$ionic products. Taking into consideration the relative amplitude of ground state bleach at 500 fs and $1 \mathrm{~ns}$ upon 420- and 310-nm excitation, which is $8 / 1$ and $3 / 1$, respectively, one may conclude that about $3 \%(420 \mathrm{~nm})$ and $12 \%(310 \mathrm{~nm})$ of the $\mathrm{CuCl}_{4}{ }^{2-}$ LMCT population undergo ionic dissociation to $\mathrm{Cu}^{\mathrm{II}} \mathrm{Cl}_{3}{ }^{-}$and $\mathrm{Cl}^{-}$. The different relative yields for the different excitation wavelengths indicates that ionic dissociation occurs from the different LMCT excited states, and that LMCT states lying at higher energies dissociate more efficiently. The remaining LMCT population returns back to the ground state via internal conversion.

Copper(II) complexes are labile, i.e. are characterized by large ligand exchange rates [40-43], and the ionic products are expected to recombine after some time to reform the parent complexes. Therefore, the quantum yields of the primary ionic dissociation reaction cannot be reliably determined using steady-state methods alone. A fraction of the radical products may reform the parent complex on a long ( $>1 \mathrm{~ns}$ ) timescale, whereas the remaining fraction may react with other compounds present in solution [21-26]. Possible recombination of the radical products after $1 \mathrm{~ns}$ and assumptions made when estimating the ground-state bleach amplitudes in the 500-fs and 1 -ns $\Delta A$ spectra allows us to compare the transient absorption and steady-state photolysis results only qualitatively. Both methods suggest that the copper(II) photoreduction efficiency decreases in the series: $\mathrm{CuCl}^{+}>\mathrm{CuCl}_{3}{ }^{-}>\mathrm{CuCl}_{4}{ }^{2-}$. The redox potential, as shown in Supplementary Materials, decreases in the $\mathrm{Cu}^{2+}>\mathrm{CuCl}^{+}>\mathrm{CuCl}_{2}>\mathrm{CuCl}_{3}{ }^{-}>\mathrm{CuCl}_{4}{ }^{2-}$ series, which is the trend coincident with the copper(II) photoreduction efficiency. Therefore, the ionic dissociation products are probably formed directly from the LMCT excited states as well as via electron transfer in a radical pair (through oxidation of a copper(I) complex fragment by a chlorine atom fragment).

\section{Conclusions}

The photochemistry of three copper(II) chlorocomplexes in acetonitrile, $\left[\mathrm{Cu}(\mathrm{MeCN})_{3} \mathrm{Cl}\right]^{+},\left[\mathrm{Cu}(\mathrm{MeCN}) \mathrm{Cl}_{3}\right]^{-}$, and $\left[\mathrm{CuCl}_{4}\right]^{2-}$ (for briefness, $\mathrm{CuCl}^{+}, \mathrm{CuCl}_{3}{ }^{-}$, and $\mathrm{CuCl}_{4}{ }^{2-}$; the general formula $\left[\mathrm{Cu}^{\mathrm{II}} \mathrm{Cl}_{n}\right]^{2-n}$, where $n=1,3$, and 4 ) is studied by the combination of the steady-state photolysis and ultrafast transient absorption methods enabling us to reveal the main relaxation pathways of the initially excited ligand-to-metal charge transfer (LMCT) state, Figure 7. A major fraction of the LMCT-excited chlorocomplexes returns back to the original ground state via internal conversion, which involves the relaxation to the vibrationally hot ground and LF excited states. A minor fraction of the LMCT excited chlorocomplexes dissociates forming either ionic products without photoreduction of copper(II), $\left[\mathrm{Cu}^{\mathrm{II}} \mathrm{Cl}_{n-1}\right]^{3-n}+\mathrm{Cl}^{-}$, or radical products with photoreduction of copper(II) to copper(I), $\left[\mathrm{Cu}^{\mathrm{I} C l_{n-1}}\right]^{2-n}+\mathrm{Cl}^{\bullet}$. The ionic dissociation occurs from the different LMCT excited states, whereas the radical dissociation mainly originates from the lowest-energy LMCT excited state. The ionic dissociation products recombine back to the original complex due to high lability of the copper(II) complexes. The radical dissociation products recombine back to the parent complex only partially. However, a fraction of the radical dissociation products undergoes further reactions, e.g. with the solvent molecules, resulting in long-lived photoreduction products, which include copper(I) complexes. The copper(II)-to-copper(I) photoreduction quantum yields are defined by the initial, presumably ultrafast, photolysis steps and are not affected by the presence of oxygen. Thus, $\mathrm{CuCl}^{+}$has the photoreduction quantum yield of $\sim 5 \%$, which corresponds to the radical dissociation product yield of $\sim 20 \%$ at $1 \mathrm{~ns}$, both yields are the largest in the investigated series. $\mathrm{CuCl}_{3}{ }^{-}$has the photoreduction quantum yield of $\sim 1.5 \%$ and the radical dissociation product yield of $\sim 2 \%$ at $1 \mathrm{~ns}$. $\mathrm{CuCl}_{4}{ }^{2-}$ is found to be photostable, which is in agreement with the ultrafast spectroscopy results, which indicate the presence of a single ionic dissociation channel.

\section{Acknowledgments}

A.S.M acknowledges Saint-Petersburg State University for the financial support (postdoctoral fellowship No. 12.50.1562.2013). The authors acknowledge A.G. Kudrev for useful discussions and D.V. Semenok for the preparation of solutions. Steady-state photolysis measurements were performed at the Center for Optical and Laser Materials Research of Saint-Petersburg State University. Measurements of the transient absorption and the absorption spectra of the individual copper(II) chlorocomplexes were performed at the Center for Photochemical Sciences, Bowling Green State University. 
This work was supported by the NSF CAREER award (Grant CHE0847707, A.N.T.), NSF MRI program (Grant CHE-0923360, A.N.T.), and RFBR (Grant 14-03-01003K.A.B.).

\section{Appendix A. Supplementary data}

Supplementary material related to this article can be found, in the online version, at doi:10.1016/j.cplett.2014.10.016.

\section{References}

[1] E. Solomon, L. LaCroix, D. Randall, Pure Appl. Chem. 70 (1998) 799.

[2] D.M. Danks, P.E. Campbell, B.J. Stevens, V. Mayne, E. Cartwright, Pediatrics 50 (1972) 188.

[3] D.M. Danks, B.J. Stevens, P.E. Campbell, J.M. Gillespie, J. Walker-Smith, J. Bloomfield, B. Turner, Lancet 1 (1972) 1100.

[4] C.A. Owen Jr., Copper Deficiency and Toxicity: Acquired and Inherited, in Plants, Animals and Men, Noyes Publications, New Jersey, 1981.

[5] E.D. Harris, Trace Elements in Health, Butterworths, London, 1983, pp. 44.

[6] I. Sternlieb, Med. Radiogr. Photogr. 42 (1966) 14.

[7] J.M. Walshe, Lancet i (1960) 188.

[8] A.G. Sykes, Chem. Soc. Rev. 14 (1985) 283.

[9] C. Dennison, A.T. Lawler, Biochemistry 40 (2001) 3158.

[10] M. Koch, M. Velarde, M.D. Harrison, S. Echt, M. Fischer, A. Messerschmidt, C. Dennison, J. Am. Chem. Soc. 127 (2005) 158.

[11] Y. Nagasawa, et al., Phys. Chem. Chem. Phys. 12 (2010) 6067.

[12] T. Cimei, A.R. Bizzarri, G. Cerullo, S. De Silvestri, S. Cannistraro, Biophys. Chem. 106 (2003) 221

[13] S. Nakashima, Y. Nagasawa, K. Seike, T. Okada, M. Sato, T. Kohzuma, Chem. Phys. Lett. 331 (2000) 396.

[14] D. Edington, W.M. Diffey, W.J. Doria, R.E. Riter, W.F. Beck, Chem. Phys. Lett. 275 (1997) 119

[15] L.D. Book, D.C. Arnett, H.B. Hu, N.F. Scherer, J. Phys. Chem. A 102 (1998) 4350.

[16] T. Cimei, A.R. Bizzarri, S. Cannistraro, G. Cerullo, S. De Silvestri, Chem. Phys. Lett. $362(2002) 497$
[17] A.R. Bizzarri, D. Brida, S. Santini, G. Cerullo, S. Cannistraro, J. Phys. Chem. B 116 (2012) 4192

[18] C. Delfino, K. Manzoni, C. Sato, G. Dennison, S. Cerullo, Cannistraro, J. Phys. Chem. B 110 (2006) 17252

[19] E.M. Glebov, V.F. Plyusnin, V.P. Grivin, S.A. Krupoder, T.I. Liskovskaya, V.S Danilovich, J. Photochem. Photobiol. A: Chem. 133 (2000) 177.

[20] P.A.C. da Silva, P.G. David, Bull. Chem. Soc. Jpn. 55 (1982) 2673.

[21] P.G. David, P.A.C. da Silva, Bull. Chem. Soc. Jpn. 58 (1985) 3566

[22] H. Kaczmarek, A. Kaminska, L.A. Linden, J.F. Rabek, Polymer 37 (1996) 4061

[23] J.K. Kochi, J. Am. Chem. Soc. 84 (1962) 2121.

[24] P. Cieśla, P. Kocot, P. Mytych, Z. Stasicka, J. Mol. Catal. A - Chem. 224 (2004) 17.

[25] E. Cervone, F.D. Camassei, I. Giannini, J. Sykora, J. Photochem. 11 (1979) 321

[26] G. Ferraudi, S. Muralidharan, Coord. Chem. Rev. 36 (1981) 45.

[27] D.R. McMillin, K.M. McNett, Chem. Rev. 98 (1998) 1201.

[28] K. Ando, J. Phys. Chem. B 108 (2004) 3940.

[29] K. Ando, J. Phys. Chem. B 112 (2008) 250.

[30] A.S. Mereshchenko, S.K. Pal, K.E. Karabaeva, P.Z. El-Khoury, A.N. Tarnovsky, J. Phys. Chem. A 116 (2012) 2791.

[31] B.J. Hathaway, D.G. Holah, J.D. Postlethwaite, J. Chem. Soc. (1961) 3215, Jplus Consulting/ReactLab.

[32] EQUILIBRIA. http://jplusconsulting.com/products/reactlab-equilibria/ucts/ reactlab-equilibria (accessed 10.06.14).

[33] KTH, Chemistry/Chemical Equilibrium Diagrams. http://www.kth.se/en/che/ medusa (accessed 10.06.14).

[34] S.K. Pal, A.S. Mereshchenko, P.Z. El-Khoury, A.N. Tarnovsky, Chem. Phys. Lett. 507 (2011) 69 .

[35] I. Persson, J.E. Pennerhahn, K.O. Hodgson, Inorg. Chem. 32 (1993) 2497.

[36] A.G. Kudrev, Talanta 101 (2012) 157

[37] S.-i. Ishiguro, B.G. Jeliazkova, H. Ohtaki, Bull. Chem. Soc. Jpn. 58 (1985) 1749

[38] U.K. Kläning, T. Wolff, Ber. Bunsen - Ges. Phys. Chem 89 (1985) 243.

[39] A.S. Mereshchenko, Ultrafast Photochemistry of Polyatomic Molecules Containing Labile Halogen Atoms in Solution (Ph.D.), Bowling Green State University, Bowling Green, OH, USA, 2013.

[40] M. Eigen, R.G. Wilkins, Adv. Chem. Ser. 49 (1965) 55.

[41] L. Helm, A.E. Merbach, Chem. Rev. 105 (2005) 1923.

[42] L. Helm, S.F. Lincoln, A.E. Merbach, D. Zbindenla, Inorg. Chem. 25 (1986) 2550

[43] A. Pasquarello, et al., Science 291 (2001) 856 